\title{
Damage caused by citrus canker on Valencia sweet orange yield
}

\author{
Daños causados por cancro cítrico en la producción de \\ naranja dulce 'Valencia'
}

\author{
Eduardo Cesar Brugnara ${ }^{1 *}$, Gustavo de Faria Theodoro ${ }^{2}$, Cristiano Nunes Nesi ${ }^{1}$, \\ Luiz Augusto Ferreira Verona ${ }^{1}$, Antonio Carlos Maringoni ${ }^{3}$
}

\begin{abstract}
The citrus canker, caused by Xanthomonas axonopodis pv. citri, is one of the main citrus diseases and has threatened the world's citriculture. In this study, the damage caused by citrus canker was quantified in a sweet orange culture, cv. Valencia [Citrus sinensis (L.) Osb.], grafted over 15 year-old Rangpur lime (C. limonia Osb.), in the municipality of Guatambu, SC, Brazil, in the crop of 2004/05. Evaluations of the number of fruits per plant (NF), fruit yield per plant (P), citrus canker incidence on the fruit (IFR), and incidence (IL) and severity (SV) of citrus canker on 80 leaves per orange tree were performed in the harvest period, applying diagrammatical scales. Plants had large variation in SV (0.16\%-1.09\%), IL (12.50\%-56.25\%) and IFR (12.30\%-56.09\%). Linear regressions were significant between IL $x$ SV, NF $x$ SV, P $x$ IFR, and NF $x$ IFR. There was no significant difference (p>0.05) between the mean estimated values of IL in different quadrants of the crowns of the orange trees (N, S, L and O). Each $1 \%$ increase in IFR reduced $2.16 \mathrm{~kg}$ and 21.3 fruits per tree.
\end{abstract}

Key words: Citrus sinensis, Xanthomonas axonopodis pv. citri, incidence, severity.

\section{RESUMEN}

El cancro cítrico causado por Xanthomonas axonopodis pv. citri, es una de las principales enfermedades de los cítricos y tiene amenazada la industria de los cítricos en todo el mundo. En este trabajo se cuantificó el daño causado por el cancro cítrico en la producción de naranja dulce cv. Valencia [Citrus sinensis (L.) Osb.] injertada en limón 'Cravo'(C. limonia Osb.), con 15 años de edad, en el municipio de Guatambú, SC, Brasil, en la cosecha 2004/05. En el momento de la cosecha, se evaluó el número de frutos por planta $(N F)$, el rendimiento de frutos por planta $(R)$, la incidencia de cancro en los frutos (IFR) y la incidencia (IFL) y severidad (SV) de cancro en 80 hojas/planta, utilizando escalas diagramáticas. Las plantas presentaron gran variación en $S V$ (de 0,16 a 1,09\%), IFL (12,50 a 56,25\%) y IFR (12,30 a 56,09\%). Fue posible adaptarse regresiones lineales simples entre IFL $x S V, N F x S V, R$ x IFR y entre NF x IFR. No hubo diferencias significativas ( $p>0,05)$ entre los medios de IFL estimados en los diferentes cuadrantes de la copa de las plantas ( $N, S, E y O)$. A cada incremento de $1 \%$ en IFR se reduce la producción por planta en 2,16 kg y 21,3 frutos.

Palabras clave: Citrus sinensis, Xanthomonas axonopodis pv. citri, incidencia, severidad.

\section{Introduction}

Citrus culture in the eastern region of Santa Catarina state in southern Brazil occupies about three thousand hectares and involves more than three thousand farmer families in a system of small orchards whose main market is the orange juice industry. According to Theodoro et al. (2005a, b) the incident diseases on Valencia sweet orange orchards in Santa Catarina are postbloom fruit drop (Colletotrichum acutatum (Penz) Sacc), scab (E. fawcettii Bitancourt $\&$ Jenkins), pink disease (Corticium salmonicolor Berk. \& Br.), leprosis (Citrus leprosis virus), root rot (Phytophthora spp.), black spot (Guignardia citricarpa Kiely), citrus variegated chlorosis or CVC (Xylella fastidiosa Wells et al.) and citrus canker.

1 Epagri - Empresa de Pesquisa Agropecuária e Extensão Rural de Santa Catarina. Adress: Servidão Ferdinando Tusset, C.P. 791, CEP 89801-970 - Chapecó, SC, Brazil. E-mail: eduardobrugnara@epagri.sc.gov.br.* Corresponding author.

2 UFMS - Universidade Federal de Mato Grosso do Sul, Campus of Chapadão do Sul, Chapadão do Sul, MS, Brazil.

3 UNESP - Universidade Estadual Paulista Júlio de Mesquita Filho, Faculdade de Ciências Agronômicas, Botucatu, SP, Brazil.

Fecha de Recepción: 9 Enero, 2012.

Fecha de Aceptación: 6 Marzo, 2012. 
Citrus canker, caused by Xanthomonas axonopodis pv. citri, is one of the main diseases that occurs in citrus plants and has been a serious threat to world citriculture. The disease causes straw or brown colored necrotic eruptive lesions, with corky-looking fruits, leaves and branches. Fruit lesions, similar to those present on the leaves, can cause premature fruit drop; the susceptibility period varies among species (Graham et al., 1992).

According to Savary et al. (2006), the study of the influence of plant diseases on the reduction of agricultural output contributes to the targeting of resources destined to research and to professional care in the management of diseases in the field. Damage in the vegetative development and yield of soursop fruit caused by the soursop yellow blotch virus (SYBV) was studied by Santos et al. (2007), who showed that the disease reduced plant height and stem diameter by $65.11 \%$ and $46.72 \%$, respectively, and the number and weight of fruit by $94.7 \%$ and $99.2 \%$, respectively, compared to healthy plants. To characterize and quantify the damages caused by citrus sudden death, Bassanezi et al. (2005) evaluated the fruit yield of citrus cultures in the north region of São Paulo state and in the southeast region of Minas Gerais state (commonly known as the "Triângulo Mineiro"), in Brazil. The damages were characterized by reduction in total weight of fruit per plant, total number of fruits per plart and fruit size. Orange varieties did not differ in reduction, but younger plants had a greater reduction in the total number of fruits per plant and plants more than five years old showed reduction in fruit size.

The aim of the present study was to estimate the damage caused by the citrus canker in the yield of Valencia sweet orange.

\section{Material and Methods}

This experiment was performed in the municipality of Guatambú, Santa Catarina state - Brazil ( $27^{\circ} 07^{\prime} 40^{\prime \prime} \mathrm{S}$ and $\left.52^{\circ} 47^{\prime} 15^{\prime \prime} \mathrm{W}\right)$, which has a humid mesothermic climate (Cfa of Köppen-Geiger) (Kottek et al., 2006). An orchard of Valencia (Citrus sinensis (L.) Osb.) sweet orange (the most cultivated in Santa Catarina), grafted over 15 year-old Rangpur lime (C. limonia Osb.), 4 x 4m spacing, was used. Fertilization and other cultural treatments were applied according to the technical recommendations for orange culture (Koller, 1994).
Thirty four (34) plants from the orchard were chosen randomly and the number of fruits produced per plant (NF), fruit mass per plant $(\mathrm{P})$, mean mass of fruit infected by canker (MMFC) and without canker infection (MMFW), incidence of canker on fruit (IFR) and leaves (IL), and the severity on leaves (SV) were quantified. The incidence and severity were evaluated applying diagrammatical scales proposed by Belasque Jr. et al. (2005) in samples of 80 leaves per plant, with the observation of 20 leaves per plant quadrant (North, South, East and West). The evaluations were carried out in the crop of 2004/05, in the second fortnight of September, harvest season.

Data of IL and SV from each quadrant were submitted to analysis of variance, applying to the original data a BoxCox transformation (Box and Cox, 1964). In addition, the fruit mass was submitted to analysis of variance to verify the effect of the incidence of citrus canker on orange fruit. To quantify the effect of citrus canker in the production, linear regression models were fitted, using IL, IFR and SV as independent variables, and $\mathrm{P}$ and NF as dependent. For this analysis SV and IL data were grouped into classes according to the frequency distribution, fitting the regression model with the mean observations of each class. All the analyses were made with the statistical software $R$ (R Development Core Team, 2010).

\section{Results and Discussion}

Table 1 presents the descriptive statistics of the studied variables. The distribution of the disease was uneven among plants; IL, IFR and specially SV had coefficients of variation greater than $30 \%$. SV varied from $0.16 \%$ to $1.09 \%$, while mean IL was $34 \%$ with range from $12.3 \%$ to $56 \%$ (Table 1). IL and IFR were very similar, but the two variables were not significantly correlated $(\mathrm{r}=0.33 ; \mathrm{p}>0.05)$.

No significant differences were found between the mean values of IL and SV of the four quadrants of the tree crown (Table 2). The yield varied from 85 to $228 \mathrm{~kg}$ of fruit per plant, and NF from 386 to 1,451 fruits per plant, with an estimated yield of $89.3 \mathrm{t} / \mathrm{ha}$. The mean mass of fruit without canker symptoms did not differ significantly from those that presented symptoms of the disease, 184 and $186 \mathrm{~g}$, respectively. 
Table 1. Descriptive statistics of the analyzed variables of Valencia orange trees. Estadística descriptiva de las variables analizadas en naranja dulce 'Valencia'.

\begin{tabular}{|c|c|c|c|c|c|c|c|}
\hline Variable & $\begin{array}{l}\text { SV } \\
(\%)\end{array}$ & $\begin{array}{l}\text { IL } \\
(\%)\end{array}$ & $\begin{array}{l}\text { IFR } \\
(\%)\end{array}$ & $\begin{array}{c}\mathrm{P} \\
\text { (kg/plant) }\end{array}$ & $\mathrm{NF}$ & $\begin{array}{c}\text { MMFC } \\
(\mathrm{g})\end{array}$ & $\begin{array}{c}\text { MMFW } \\
\text { (g) }\end{array}$ \\
\hline Minimum & 0.16 & 12.50 & 12.30 & 85.0 & 386.0 & 141 & 120 \\
\hline Maximum & 1.09 & 56.25 & 56.09 & 228.0 & 1451.0 & 248 & 253 \\
\hline Mean & 0.48 & 34.30 & 35.41 & 142.9 & 815.1 & 184 & 186 \\
\hline C.V.(\%) & 48 & 33 & 33 & 24 & 36 & 15 & 18 \\
\hline
\end{tabular}

$\mathrm{SV}=$ severity $(\%), \mathrm{IL}=$ incidence on leaves; IFR = incidence on fruit; $\mathrm{P}=$ fruit mass per plant; $\mathrm{NF}=$ number of fruits per plant; $\mathrm{MMFC}=$ mean mass of fruit infected by canker; MMFW = mean fruit mass without canker. $\mathrm{CV}=\mathrm{Coefficient}$ of variation.

Table 2. Mean incidence and severity of citrus canker on Valencia orange tree leaves by tree quadrant. Incidencia y severidad promedios de cancro cítrico en hojas de naranja dulce 'Valencia' de acuerdo con el cuadrante de la planta.

\begin{tabular}{lccccc}
\hline Variable & North & South & West & East & $p$ \\
\hline Incidence & 37.8 & 32.3 & 36.1 & 30.6 & 0.25 \\
Severity & 0.57 & 0.39 & 0.52 & 0.44 & 0.10 \\
\hline
\end{tabular}

Table 3 presents the regressions between the studied variables that showed a level of significance less than $5 \%$. The relation between SV and IL was highly significant and with a coefficient of determination of 0.71 . Thus evaluation of canker incidence on leaves can provide data as relevant as those that estimate the severity of the disease, through the use of diagrammatical scales.

The variable IFR was the best to explain the reduction in mass and number of fruits, followed by IL and SV (Table 3 ).

Theisen (2007) observed with 12 and 13 yearold Valencia orange trees in Rio Grande do Sul state an incidence of citrus canker on leaves of less than $3 \%$, while this study found an incidence of $34 \%$. The Valencia cultivar is considered moderately susceptible (Burhan et al., 2007) or susceptible (Zubrzycki e Zubrzycki, 1988) to citrus canker, which agrees with the present observations. Conversely, the incidence of citrus canker in fruit was similar to that observed by Theisen (2007).

High variability was observed between plants in the SV data, which can be explained by the probable aggregated distribution of the disease (Gottwald et al., 2007; Rosa, 2010). However, according to Amorim and Bergamin Filho (2001), the introduction of the citrus leafminer in Brazilian citrus cultivated areas altered the spatial pattern of the citrus canker from highly aggregated (infected plants very close to each other) to moderately aggregated and even random patterns. The efficient control of Ageniaspis citricola in western Santa Catarina through the use of biological control agents (Milanez et al., 2003), associated with the application of random sampling both inside and outside the supposed aggregation area, contributed to the observed values. Severity (SV) lower than $1.1 \%$ is considered low in the scale proposed by Belasque Jr. et al. (2005). Behlau et al. (2007) observed severity lower than $2 \%$ in Pêra Rio orange trees in the northeast of Paraná state.

The variable that best explained the reduction in yield (P and NF) was canker incidence in fruit (IFR), probably because it is directly connected to fruit drop. Graham and Leite Jr. (2004) verified the reduction of fruit drop and canker incidence in Valencia oranges as an effect of chemical control. In this study, for every $1 \%$ of IFR reductions of $2.16 \mathrm{~kg}$ and 21.3 fruits per plant were observed.

The amount of disease observed in the leaves did not show a strong relation to fruit production. Young fruit are more susceptible to the disease untill 106 days after the petals have fallen (Graham et al., 1992), a period that extends from the end of winter until the beginning of the summer. Leaves are more susceptible when their expansion is between 50 and 
Table 3. Fitted models for significant relations between analyzed variables.

Modelos ajustados para las relaciones significativas entre las variables.

\begin{tabular}{llcr}
\hline Variables & Linear regression & $\mathrm{R}^{2}$ & Significance $(\alpha)$ \\
\hline IL x SV & $\mathrm{SV}=-0.10672+0.01716 * \mathrm{IL}$ & 0.71 & $<0.001$ \\
P x IFR & $\mathrm{P}=219.5401-2.1642 * \mathrm{IFR}$ & 0.53 & $<0.001$ \\
NF x IFR & $\mathrm{NF}=1570.133-21.322 * \mathrm{IFR}$ & 0.73 & $<0.001$ \\
P x SV & $\mathrm{P}=164.77-42.92 * \mathrm{SV}$ & 0.41 & 0.046 \\
NF x SV & $\mathrm{NF}=1125.1-535 * \mathrm{SV}$ & 0.42 & 0.041 \\
P x IL & $\mathrm{P}=180.0971-1.1132 * \mathrm{IL}$ & 0.69 & 0.003 \\
NF x IL & $\mathrm{NF}=1214.449-11.392 * \mathrm{IL}$ & 0.53 & 0.017 \\
\hline
\end{tabular}

$\mathrm{SV}=$ severity $(\%), \mathrm{IL}=$ incidence on leaves; $\mathrm{IFR}=$ incidence on fruit; $\mathrm{P}=$ fruit mass per plant; $\mathrm{NF}=$ number of fruits per plant; $\mathrm{MMFC}=$ mean mass of fruit infected by canker; $\mathrm{MMFW}=$ mean fruit mass without canker. $\mathrm{R}^{2}=$ Coefficient of determination.

$80 \%$ (Bergamin-Filho and Hughes, 2000), which occurs in at least three distinct periods (vegetative flush) in southern Brazil. So leaves continue to be infected throughout the summer, in opposition to fruits.

The influence of citrus canker in the yield of plants probably varies according to the cultivation methods applied and the citrus development phases. This supposition stimulates studies using different genotypes and periodic evaluations to obtain data of the area under the disease progress curve (AUDPC). However, searching to evaluate the effect of the agent that causes bean bacterial blight (Xanthomonas axonopodis pv. phaseoli) on photosynthetic efficiency and production of bean genotypes (Phaseolus vulgaris), Díaz et al. (2001) did not find any significant correlation between yield and AUDPC. This fact was attributed to the indeterminate growth habit of the bean cultures studied.

The main quantitative damage to orange production attributed to canker is premature fruit drop (Laranjeira et al., 2005). This study established a relation between canker incidence on fruit and plant yield. The estimate yield of $89 \mathrm{t} / \mathrm{ha}$ is high compared to literature data (Tazima et al., 2008; Auler et al., 2011); even in orchards with wider spacing, for example $7 \times 3 \mathrm{~m}$, would present an yield of $68 \mathrm{t} / \mathrm{ha}$, considering the yield per tree measured in this work. Although the increase of citrus canker incidence reduces yield, the disease was not a limiting factor to Valencia cultivation in the conditions of this experiment.

The data obtained in the present study is new in Brazil, contributing to a better understanding of the pathosystem studied, and indicates the need for more field studies to clarify the influence of citrus canker in the production of other genotypes of sweet orange trees.

\section{Conclusion}

An increase of $1 \%$ in citrus canker incidence in fruits of Valência orange causes reduction of $2.16 \mathrm{~kg}$ and 21.3 fruits per plant.

\section{Literature Cited}

Amorim, L.; Bergamin Filho, A

2001 A epidemiologia do cancro cítrico. Summa Phytopathologica 27: 151-156.

Bassanezi, R.B. et al.

2005 Danos da Morte Súbita dos Citros sobre a produção de laranja. Fitopatologia Brasileira 30: 497-503.

Auler, P.A.M. et al.

2011 Calagem e desenvolvimento radicular, nutrição e produção de laranja 'Valência' sobre porta-enxertos e sistemas de preparo do solo. Pesquisa Agropecuária Brasileira 46: $254-261$.
Behlau, F. et al.

2007 Incidência e severidade de cancro cítrico em laranja 'Pêra Rio' sob condições de controle químico e proteção com quebra-vento. Fitopatologia Brasileira 32: 311-317.

Belasque Júnior, J. et al.

2005 Escalas Diagramáticas para avaliação da severidade do cancro cítrico. Fitopatologia Brasileira 30: 387-393.

Bergamin Filho, A.; Hughes, G.

2000 Citrus canker epidemiology - methodologies and approaches: a moderated discussion session. In: Dixon, W.N. et al. (Ed.) Proceedings of the International Citrus Canker Research Workshop. Fort Pierce, 24-25. 
Box, G.E.P.; Cox, D.R.

1964 An Analysis of Transformations. Journal of the Royal Statistical Society 26: 211-252.

Burhan, M. et al.

2007 Screening of citrus cultivars for source of resistance against citrus canker under field conditions. Pakistan Journal of Botany 39: 1867-1871.

Díaz, C.G. et al.

2001 Quantificação do efeito do crestamento bacteriano comum na eficiência fotossintética e na produção do feijoeiro. Fitopatologia Brasileira 26: 71-76.

Gottwald, T.R. et al.

2007 Spatial pattern analysis of citrus canker-infected plantings in São Paulo, Brazil, and augmentation of infection elicited by the Asian leafminer. Phytopathology 97: 674-683.

Graham, J.H. et al.

1992 Penetration through leaf stomata and growth of strains of Xanthomonas campestris in citrus cultivars varying in susceptibility to bacterial diseases. Phytopathology 82 : 1319-1325.

Graham, J.H.; Leite Jr., R.P.

2004 Lack of Control of Citrus Canker by Induced Systemic Resistance Compounds. Plant Disease 88: 745-750.

Koller, O.C.

1994 Citricultura: laranja, limão e tangerina. Porto Alegre: Rigel.

Kottek, M. et al.

2006 World map of the Köppen-Geiger climate classification updated. Meteorologische Zeitschrift 15: 259-263.

Laranjeira, F.F. et al.

2005 Fungos, procariotos e doenças abióticas. In: Mattos Junior, D. et al. (eds.) Citros. Campinas: Instituto Agronômico de Campinas and Fundag, 509-566.

Milanez, J.M. et al.

2003 Introdução, adaptação e eficiência de Ageniaspis citrícola (Hymenoptera: Encyrtidae) no controle do minador-doscitros (Phyllocnistis citrella (Lepidoptera: Gracillariidae)) na região Oeste de Santa Catarina. In: Resumos do $8^{\circ}$ Simposio de Controle Biológico, São Pedro. 125.
R Development Core Team

2010 R: A language and environment for statistical computing. Vienna: R Foundation for Statistical Computing.

Rosa, J.

2010 Distribuição espacial e raio de agregação de cancro cítrico definidos por geoestatística. Tese de doutorado. Jaboticabal, Brasil. Universidade Estadual Paulista Júlio de Mesquita Filho.

Santos, A.A. et al.

2007 Efeito do Soursop yellow blotch virus (SYBV) no desenvolvimento vegetativo e na produção da gravioleira. Summa Phytopathologica 33: 90-92.

Savary, S. et al.

2006 Quantification and modeling of crop losses: a review of purposes. Annual Review of Phytopathology 44: 89-112.

Tazima, Z.H. et al.

2008 Comportamento de clones de laranja 'Valência' na região norte do Paraná. Revista Brasileira de Fruticultura 30: 970-974.

Theisen, S.

2007 Incidência de cancro cítrico (Xanthomonas axonopodis pv. citri) em pomares de laranjeiras 'Valencia' com poda sanitária e pulverizações com produtos cúpricos, abamectin e calda sulfocálcica. Tese de doutorado. Porto Alegre RS. Universidade Federal do Rio Grande do Sul.

Theodoro, G.F. et al.

2005a Incidência de doenças em laranjeiras doce na região oeste de Santa Catarina. Summa Phytopathologica 31 (Supl.): 29.

Theodoro, G.F. et al.

2005b Intensidade da clorose variegada dos citros em pomares de laranjeira doce no Oeste Catarinense. Agropecuária Catarinense 18: 91-94.

Zubrzycki, H.M.; Zubrzycki, A.D.

1988 Evaluación de resistencia a concrose en citros com diferentes niveles de inoculo en infecciones naturales a campo. Boletin Genetico 15: 21-29. 
